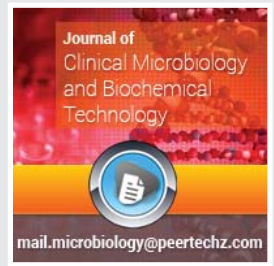

\title{
Bacterial resistance genetic markers (fluoroquinolone, aminoglycosideo, macrolideo)
}

\author{
Antonio Linkoln Alves Borges Leal ${ }^{1,2 *}$, Gabryella Karolliny \\ Antunes Araujo ${ }^{2}$ and Samuel Martins Ribeiro Neto $^{2}$ \\ 'Department of Biological Chemistry, Regional University of Cariri, Crato (CE), Brazil \\ ${ }^{2}$ Departament of Parasitology and Microbial, Federal University of Piauí, Teresina (PI), Brazil
}

Received: 10 February, 2020

Accepted: 10 March, 2020

Published: 11 March, 2020

*Corresponding author: Antonio Linkoln Alves Borges Leal, Departament of Parasitology and Microbial, Federal University of Piauí, Teresina (PI), Brazil, Tel: +55 (99) 984297761; E-mail: antoniolinkoln@hotmail.com

Keywords: Gene; Plasmid; Resistance; Antimicrobial; Fluoroquinolone; Aminoglycoside; Macrolide

https://www.peertechz.com

\section{Check for updates}

\begin{abstract}
Bacterial resistance is a natural biological phenomenon, defined as an ability to multiply the presence of high temperatures of antimicrobials reached in therapeutic doses. Currently, there has been a large increase in the number of deaths related to hospital infections, being closely linked to resistant microorganisms. Knowledge of the genes responsible for the expression of resistance in the presence of high doses of antibiotics is of great importance, as it favors a more effective treatment, with the correct use of drugs and with a response effect in much less time, in addition to reducing levels of new cases of bacterial resistance. The objective of this work is to present high knowledge about the genetic markers of resistance in the main classes of antibiotics, fluoroquinolone, aminoglycoside and macrolides, using articles, technical manuals that describe the genetic markers of resistance. Different types of genes, plasmids and/or resistance markers to the main antibiotics. It can highlight what the work has to do precisely on the main genes expressed, when in contact with the antibiotics selected at work.
\end{abstract}

\section{Introduction}

Bacterial resistance is a natural biological phenomenon, which is defined as the ability to multiply in the presence of high concentrations of antimicrobial achieved with therapeutic doses [1]. Historically, control of systemic bacterial infections began in 1935 [2].

Soon after the introduction of penicillin in clinical practice, most strains of Staphylococcus aureus that were sensitive, today less than $5-10 \%$. Just as when strains of Escherichia coli and Klebsiella pneumoniae were sensitive to Cefotaxime when it was used in the clinic in the early eighties of the twentieth century; nowadays 13 and $16 \%$ respectively are resistant. When have been marketed, fluoroquinolones in the mid-eighties, practically all E. coli strains were sensitive; currently $34 \%$ of blood cultures in Spain are resistant [3].

The term bacterial resistance has other known denominations, relative or intermediate resistance: Where there is a gradual increase of the Minimum Inhibitory Concentration (MIC) over time. In order to have a therapeutic effect it is necessary to achieve adequate serum and tissue levels; absolute resistance: Where the sudden increase in MIC of a culture occurs during or after therapy. Antibiotic tolerance is known as a phenomenon where the Minimum Bactericidal Concentration (MBC) and MIC is very large [4].

Resistance mechanisms preexist or are modified by nature, either by transfer of resistance genes or by mutations, which can be localized in the bacterial chromosome or in plasmids [1]. There are several mechanisms of bacterial resistance, such as; enzymatic inactivation, reduced intracellular accumulation due to the action of efflux pumps, the presence of transposons, resistance plasmids, and the capacity for transduction, transformation and conjugation [5].

The dissemination of genetic knowledge corroborates the rapid implementation of the management plan on the treatment of the various types of resistant infections, previous knowledge favors to avoid administration of antibiotics in a widespread and indiscriminate way.

\section{Methodology}

Published articles, technical manuals describing the different types of genes, plasmids and/or resistance markers to 
the main antibiotics were used. Only works with precise results of the created genes are used, excluding all other items related to the subject.

Taking into account or drastic problem of global public health. The work was developed to report a genetic diversity expressed in cases of microorganisms when it is under the action of known antibiotics.

\section{Mechanisms de resistance bacterium}

Bacterial resistance to antimicrobials occurs when bacteria generate skills in order to defend themselves from harmful substances, creating alternative defense mechanisms. There are several resistance mechanisms, including basic division through intrinsic and acquired resistance, in which due to a large portion of antimicrobials come from molecules in the environment, bacteria when in contact with these substances, acquire methods capable of containing these, there are also mutations, this mechanism, bacteria genes that prevent change in antimicrobial activity, horizontal gene transfer takes place in order to propagate resistance to other bacteria, where changes of bacteria genes are transferred as well as changes in resistance plasmids [6].

The enzymatic mechanism of bacterial resistance is also an alternative used by bacteria, where the major representatives are $\beta$-lactamases, where they chelate $\beta$-lactam antibiotics through reactions in which the drug loses its action. Active efflux is one of the most studied resistance mechanisms where they use transmembrane proteins that efflux harmful substances from the cell. Another mechanism is to reduce the permeability of the cell membrane, where bacteria stop the arrival of the antimicrobial at its target [7].

\section{Genetic markers of resistance to antibiotics main}

The genetic machinery is highly complex, briefly talking about the plasmids and transposons, these are mobile genetic elements where the resistance genes are transported. The plasmids are fragments of extracellular bacterial DNA of variable length and circular, where some are able to replicate independently of the available genetic machinery for the cell. Transposons are DNA sequences that can be translocated between chromosomes, a chromosome into a plasmid or between the plasmids themselves, due to their own recombination system, coupled with the ability of the plasmids to move to another cell during conjugation, allowing the acquisition of genes of resistance between bacteria of the same species or different species, facilitating the expansion of resistance. Some plasmids and transposons have genetic elements called integrones that allow them to capture several exogenous genes that determine the appearance of a lineage [6].

Multiresistant some of the major antibiotics that suffer particularly from this mechanism are beta-lactams, aminoglycosides, tetracyclines, chloramphenicol and sulfonamides, showing resistance by Escherichia coli and $P$. mirabilis to ampicillin [8].
Quinolone-resistant Enterobacteriaceae generally occurs in stages as a result of chromosomal mutations responsible for the modification in DNA gyrase and topoisomerase IV or due to decreased intracellular accumulation of the drug by the activation of modified outer membrane efflux pumps and/or porins. Plasmid-mediated Quinolone Resistance (QMR), QnrA was introduced in 1998, four other determinants of identified PMQRs were the QnrB and QnrS proteins, the aminoglycoside acetyltransferase AAC. (6') - Ib-cr and the efflux pump QepA. Resistance due to determinants of Qnr is increasingly reported worldwide in enterobacterial isolates and has recently been identified in Aeromonas environmental isolates withdrawn from France [9].

The principal mechanism of quinolone resistance described consists of mutations to DNA-gyrase and topoisomerase IV, modification of the antimicrobial, expression of efflux system, alteration or absence of porins and protection of the target site. Mutations in DNA-gyrase and topoisomerase IV exhibit spontaneous mutations capable of altering the antimicrobial binding site, reduced affinity, and impaired action. In DNAgyrase the substitutions occur more frequently in the gyrA gene, where the serine located at codon 83 or 87 is usually replaced by another amino acid, and less frequently in the gyrB gene. The replacement of the amino acids that occur in topoisomerase IV occur in the parC and par $\mathrm{E}$ genes, most often the parC gene. The region where it occurs is called the quinolone resistancedetermining region, where in gram-negative, these mutations occur generally in the gyrA and gram-positive genes in the parC gene [10].

In Iran, in 2009, 15 clinical isolates resistant to INH, RIF, STP, OFL, AMK ethambutol, pyrazinamide, ethionamide, para-aminosalicylic acid, Dcycloserine and ciprofloxacin were found. Mutations in the gyrA gene lead to the translation of a modified GyrA 19 protein, since gyrA is a protein subunit of the modified DNA gyrase enzyme, leading to antibiotic resistance to the presence of Fluoroquinolone. What mutations in codons $88,90,91$ and 94 of gyrA can be resistant strains to FLQ. The aminoglycosides (STP, KAN and AMK) bind to the $30 \mathrm{~S}$ subunit of the mycobacterial ribosome by inhibiting protein synthesis. STP binds to ribosomal protein S12 (encoded by the rpsL gene) and to $16 \mathrm{~S}$ ribosomal RNA (rRNA) (encoded by the rrs gene), so mutations in these two genes lead to resistance to STP [10].

Silva RVC [11]. It goes further by biochemically detailing the process of resistance to aminoglycosides, being classified in 2 large groups those containing a streptidine cycle (as is the case of streptomycin and spectinomycin) and those with a 2-deoxystreptamine nucleus with C4 substitutions (Such as, for example, neomycins), thus, these antibiotics act on ribosomal regions, interfering with the tration process. In turn the resistance to these antibiotics occur by 3 different types of enzymes; 1 ) Acetyltransferases or, more abbreviated, AAC (from the AngloSaxon expression "aminoglycoside-N-acetyltransferase"), 2) Phosphotransferases or, more abbreviated APH (from the AngloSaxon expression "aminoglyocside-O-phosphotransferase") and 3) Nucleotidyltransferases or, more abbreviated, $A A D$ (from the Anglo-Saxon expression "aminoglycoside-Onucleotidyltransferase").

Citation: Borges Leal ALA, Antunes Araujo GK, Ribeiro Neto SM (2020) Bacterial resistance genetic markers (fluoroquinolone, aminoglycosideo, macrolideo). J Clin Microbiol Biochem Technol 6(1): 004-007. DOI: https://dx.doi.org/10.17352/jcmbt.000036 
Thus, while the phosphorylation and nucleotidylation (adenylation) reactions use ATP as a factor, the acetylation reaction already uses acetyl-coenzyme A. Post-transcriptional methylation of the $16 \mathrm{~S}$ rRNA binding site to the aminoglycoside has been pointed out by [12], which identified seven $16 \mathrm{~S}$ rRNA methyltransferase (16Smethylase) genes mediated by plasmids: armA, $n p m A, r m t A, r m t B, r m t C, r m t D$ and very recently $r m t E$ of bovine origin which genes commonly associated with other researchers were; $\operatorname{arm} A, r m t A, r m t B, r m t C, r m t D, n p m A$, blaTEM, blaCTX-M, blaKPC, qnrB.

Interestingly, when treating macrolides two primary mechanisms result in resistance to this class of antimicrobials. The first involves the efflux of common macrolides in strains of S. aureus, a specific efflux pump encoded by the msrA gene in staphylococci. This energy-dependent pump effectively expels macrolides from the bacterial cell before they can bind to their target on the ribosome. This mechanism creates resistance to macrolides and streptogramin $\mathrm{B}$. The second mechanism of macrolide resistance in staphylococci would be by modifying the site of action of the antimicrobial in the ribosome. It is mediated by erm (Erythromycin ribosome methylase) genes that encode enzymes called 23S rRNA methylases, responsible for the methylation of $23 \mathrm{~S}$ rRNA. Modification by methylases reduces the binding of macrolides, lincosamides and streptogramin B to the bacterial ribosome [13].

So-and-so reports that resistance to macrolides in S. pneumoniae is found in several regions and is generally mediated by two mechanisms; ribosomal methylase activity encoded by the erm B gene and rarely by the erm a ermTR gene, resulting in highly resistant strains of macrolides, azalides and clindamycin or drug efflux encoded by the mef gene. Other mechanisms of resistance have been reported, such as mutation in L4 and L22 and mutations in 23S rRNA at position 2058 or 2611 (E. coli numbering site) [4].

\section{Principais antibióticos alvos de resistência bacteriana}

The $\beta$-lactam antibiotics are irreversibly preventing the transpepitidação reaction by the enzyme transpetidase, catalyst for such a reaction, this class is a broad spectrum. All $\beta$-lactam antibiotics have a common pharmacophoric structural medium, the four-membered azetidinone ring or $\beta$-lactam ring. Most antibiotics, the central $\beta$-lactam ring is fused to another five (thiazolidine) or six (dihydrothiazine) member ring, developing penicillins or cephalosporins, respectively. Generally, the bicyclic system is of paramount importance for the activity of these antibiotics, since it mimics the terminal dipeptide residue D-Ala-D-Ala of the peptideoglycan chain, substrate of the transpeptidase enzyme [14].

The action of $\beta$ - lactam take place through inhibition of cell wall synthesis, the transpeptidation interrupting the process, since that mechanism connects the $\beta$ lactam characteristic receptors that are found on the inner surface of the cell membrane of the bacterium, this is the "Penicillin Receptor Proteins (PRPs)", employed in the final stages of the synthesis of peptidoglycan. In order to have activity, $\beta$-lactams need to penetrate the cell wall of the bacteria, where it happens more easily in gram positive bacteria, because its glycopeptide layer is external to a single cell membrane, different from gram negative that its glycopeptide layer is between the plasma membrane and the outer cell membrane. Gram negative bacteria have a well-known mechanism of resistance, production of $\beta$-lactamases, it is necessary to understand that such resistance is mediated efficiency in the production of $\beta$-lactamase, and its antimicrobial proportional hydrolysis penetration ability and flexibility in the outer membrane of the bacterium $\beta$-lactâmico [15].

According to Baptista (2013), currently $\beta$-lactams are a class of antimicrobials most used, because of their therapeutic potency and reduced toxicity. Among them are: penicillins, cephalosporins and carbapenems. Cephalosporins and penicillins inhibit the most important enzymes for the formation of peptideoglycan, bacitracin blocks the pathway of pyrophosphate-bactoprenol to phosphoctoprenol, in gram positive bacteria, on the other hand, Carbapenems have a broader spectrum, whereas Monobactamics have action only on gram negative bacteria, and gicopeptides, inhibits the synthesis of the bacterial cell wall, by joining the D-alanyl-Dalanine end of the precursor unit of the cell wall, preventing the elongation of the peptideoglycan [16].

Example of antimicrobial whose mechanism of action destabilizes the bacterial cytoplasmic membrane is Polymyxin $\mathrm{B}$, with both hydrophilic and hydrophobic characteristics and surfactants, composed of a side chain of fatty acids, linked to a polycationic peptide ring, consisting of eight amino acids that relate to the Liposaccharides (LPS) of the bacterial cell membrane. Thus, antimicrobials of this class act on these membranes removing calcium and magnesium molecules that stabilize the membrane. Polymyxins destabilize the membrane, promoting the expansion of permeability and causing the components to be released, killing the cell [17].

Fluoroquinolones and Rifampicin are antimicrobials that inhibit the action of nucleic acids. Fluoroquinolones, such as Ciproflaxacin, Norfloxacin and Ofloxacin, act on the enzymes DNA gyrase and bacterial topoisomerase IV, where they prevent DNA from over-breathing, where it prevents the growth of bacteria, and in conditions where concentrations are high it also inhibits topoisomerase. Rifampicin, on the other hand, act by inhibiting RNA polymerase, which joins peptide chains by non-covalent means, impairing the beginning of the DNA transcription process [18-24].

Aminoglycosides, tetracyclines, amphenols, macrolides, lincosamides and oxazolinidones, are antimicrobials that act as inhibitors of bacterial protein synthesis, using bacterial ribosomes, as it has two subunits, $50 \mathrm{~S}$ and $30 \mathrm{~S}$, where in the ribosomes of mammals it is constituted by $60 \mathrm{~S}$ subunits and $40 \mathrm{~S}$, this distinction is the principle for selectivity of antimicrobials in inhibiting protein synthesis, so the unbridled use in high concentrations of antimicrobials can interfere in this protein synthesis [17].

Sulfonamides and trimethropine act in a similar way to Paraaminobenzoic Acid (PABA), where it is more used by 
bacteria in the production of folic acid, thus bacteria that need to synthesize folic acid, occasionally become resistant. However, trimethropine acts only by means of a sulfonamide, as it is a competitive and selective inhibitor of microbial reductase, therefore the conduction of these drugs occurs together blocking the synthesis of the microorganism's tetrahydrofolate from precursor molecules, interfering with cellular metabolism [16].

The data obtained in this study allow to contribute on the main resistance genes expressed on the antibiotics that were used in the therapy against these microorganisms. The dissemination of genetic knowledge corroborates the rapid execution of a management plan on several types of resistant infections before the administration of any type of drug.

\section{References}

1. García CP (2003) Bacterial resistance to antimicrobial agentes. Rev Chil Infectol 20 .

2. Horr L, Oro IM, Lorenzini A, Silva LM (1978) Hospital Infection Control Committee. Rev Bras Sick 31.

3. Alós Jl (2015) Resistencia bacteriana a los antibióticos: una crisis global. Enfermedades Infecciosas y Microbiología Clínica 33: 692-699. Link: https://bit.ly/38GuApy

4. Sussmann O, Mattos L, Restrepo A (2002) Resistencia bacteriana. Univ Med 43: 20-26.

5. Schwarz S, Loeffler A, Kadlec K (2017) Bacterial resistance to antimicrobial agents and its impact on veterinary and human medicine. Vet Dermatol 28 : 82-e19. Link: https://bit.ly/2Q1pNZu

6. Silva LFDD (2016) Design and artificial synthesis of a vector for the expression of heterologous proteins.

7. Nogueira HS, Xavier ARE, Xavier MAS, Carvalho AA. Monção GA, et al. (2016) Antibacterianos: Principais Classes, Mecanismos De Ação E Resistência. Revista Unimontes Cientifica 8. Link: https://bit.ly/38MwZzq

8. Pérez-Cano HJ, Robles-Contreras A (2013) Basic aspects of the mechanisms of bacterial resistance. Rev Med MD 4.5: 186-191. Link: https://bit.ly/3cOnxyv

9. Cattoir V, Nordmann P, Silva-Sanchez J, Espinal P, Poirel L (2008) ISEcp1Mediated Transposition of qnrB-Like Gene in Escherichia coli. Antimicrobial Agents and Chemotherapy 52: 2929-2932. Link: https://bit.ly/3aHylg7

10. de Sousa FRR (2014) Research of genes of resistance to quinolones in Gramnegative bacilli of clinical and environmental origin. Dissertation Graduate Program in Public Health, Faculty of Public Health, University of São Paulo.

11. Silva RVC (1984) da, Mechanisms of resistance to antibiotics, Lecture given in the "Cycle of Updating in Clinical Analyzes" carried out by the Order of Pharmacists.

12. Tijet N, Andres P, Chung C, Lucero C, Low DE, et al. (2011) rmtD2, a New Allele of a 16S rRNA Methylase Gene, Has Been Present in Enterobacteriaceae Isolates from Argentina for More than a Decade. Antimicrob Agents Chemother 55 904-909. Link: https://bit.ly/2wM1KXI

13. Pereira JN, Rabelo MA, Lima JL, Neto AM, Lopes AC, et al. (2014) Phenotypical And Molecular Characterization of Resistance to Macrolides, Lincosamides and Streptogramines B of Clinical Isolates of Staphylococcus Spp. Federal
University of Pernambuco- Ufpe Center for Health Sciences - Ccs Program of Postgraduation In Tropical Medicine.

14. Cattoir V, Nordmann P, Silva-Sanchez J, Espinal P, Poirel L (2008) ISEcp1Mediated Transposition of qnrB-Like Gene in Escherichia coli. Antimicrobial Agents and Chemotherapy 52: 2929-2932. Link: https://bit.ly/3aHylg7

15. Bello A, Dingle TC (2018) What's That Resistance Mechanism? Understanding Genetic Determinants of Gram-Negative Bacterial Resistance. Clinical Microbiology Newsletter 40: 165-174. Link: https://bit.ly/38FT4zl

16. Neves AL, Costa DLA (2017) Beta-lactamaseproducing gram-negative bacilli: which bla bla bla is this?. Journal of Infection Control.

17. Macedo MLAP, Cartaxo RS, Almeida TC, de Souza LB, Santana WJ, et al. (2005) Mechanisms of resistance and detection of beta-lactamases. Ciênc Biol Saúde 7: 59-63.

18. Teixeira AR, Figueiredo AFC, França RF (2019) Resistência Bacteriana Relacionada Ao Uso Indiscriminado De Antibióticos. Revista Saúde Em FocoEdição 11. Link: https://bit.ly/2xum8gr

19. Barquist L, Mayho M, Cummins C, Cain AK, Boinett CJ, et al. (2016) The TraDIS toolkit: sequencing and analysis for dense transposon mutant libraries. Bioinformatics 32: 1109-1111. Link: https://bit.ly/3816ueh

20. Ribeiro CM (2018) Perfil de resistencia a fluoroquiolona e aminoglicosideos em isolados clínicos de Mycobacterium tuberculosis. Master's Dissertation, Faculty of Pharmaceutical Sciences of Araraquara. Link: https://bit.ly/3cQPfuo

21. Vasconcelos AM, Soares FT, Vieira M, Souza L, Barreto S, et al. (2006) Mecanismo de Ação e de Resistencia aos Cetolideos. Rev Cienc Méd 15: 427436. Link: https://bit.ly/2wlnnZ8

22. Vasconcelos AM, Soares FT, Vieira M, Souza L, Barreto S, et al. (2006) Mecanismo de Ação e de Resistencia aos Cetolideos. Rev Cienc Méd 15: 427436. Link: https://bit.ly/2wlnnZ8

23. Guimarães DO, da Silva Momesso L, Pupo MT (2010) Antibióticos: importância terapêutica e perspectivas para a descoberta e desenvolvimento de novos agentes. Química Nova 33. Link: https://bit.ly/2vg5QXQ

24. Baptista MGFM (2013) Mecanismos de Resistência aos Antibióticos. Universidade Lusófona de Humanidades e Tecnologia Faculdade de Ciências e Tecnologia da Saúde. Link: https://bit.ly/2Q62rSs

Discover a bigger Impact and Visibility of your article publication with

\section{Peertechz Publications}

\section{Highlights}

* Signatory publisher of ORCID

* Signatory Publisher of DORA (San Francisco Declaration on Research Assessment)

- Articles archived in worlds' renowned service providers such as Portico, CNKI, AGRIS, TDNet, Base (Bielefeld University Library), CrossRef, Scilit, J-Gate etc.

* Journals indexed in ICMJE, SHERPA/ROMEO, Google Scholar etc.

- OAI-PMH (Open Archives Initiative Protocol for Metadata Harvesting)

* Dedicated Editorial Board for every journal

* Accurate and rapid peer-review process

- Increased citations of published articles through promotions

* Reduced timeline for article publication

Submit your articles and experience a new surge in publication services (https://www.peertechz.com/submission).

Peertechz journals wishes everlasting success in your every endeavours.

Copyright: ๑) 2020 Borges Leal ALA, et al. This is an open-access article distributed under the terms of the Creative Commons Attribution License, which permits unrestricted use, distribution, and reproduction in any medium, provided the original author and source are credited. 